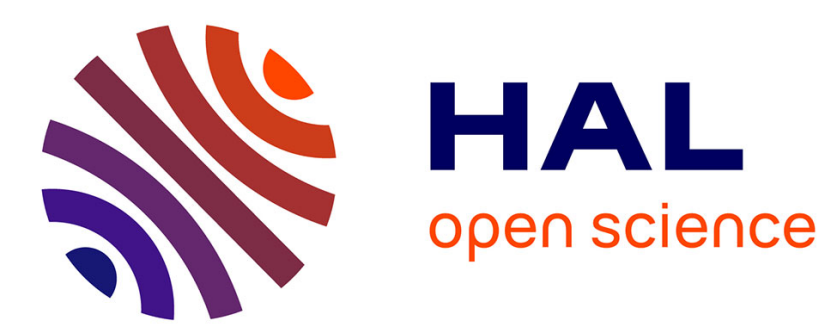

\title{
Innate immunity in lophotrochozoans: the annelids.
}

M. Salzet, A. Tasiemski, E. Cooper

\section{To cite this version:}

M. Salzet, A. Tasiemski, E. Cooper. Innate immunity in lophotrochozoans: the annelids.. Current Pharmaceutical Design, 2006, 12 (24), pp.3043-3050. hal-00086941

\section{HAL Id: hal-00086941 https://hal.science/hal-00086941}

Submitted on 18 Aug 2007

HAL is a multi-disciplinary open access archive for the deposit and dissemination of scientific research documents, whether they are published or not. The documents may come from teaching and research institutions in France or abroad, or from public or private research centers.
L'archive ouverte pluridisciplinaire HAL, est destinée au dépôt et à la diffusion de documents scientifiques de niveau recherche, publiés ou non, émanant des établissements d'enseignement et de recherche français ou étrangers, des laboratoires publics ou privés. 


\title{
INNATE IMMUNITY IN LOPHOTROCHOZOANS: THE ANNELIDS
}

\author{
Michel Salzet ${ }^{1}$, Aurélie Tasiemski ${ }^{1}$, Edwin $_{\text {Cooper }}^{2}$ \\ ${ }^{1}$ Laboratoire de NeuroImmunologie des Annélides, UMR CNRS 8017, SN3, Université des \\ Sciences et Technologies de Lille, 59655 Villeneuve d'Ascq Cedex, France. \\ ${ }^{2}$ Laboratory of Comparative NeuroImmunology, Department of Neurobiology \\ David Geffen School of Medicine at UCLA, University of California \\ Los Angeles, California 90095-1763, USA
}

\begin{abstract}
:
Innate immunity plays a major role as a first defense against microbes. Effectors of the innate response include pattern recognition receptors (PRR), phagocytic cells, proteolytic cascades and peptides/proteins with antimicrobial properties. Each element of these events has been well studied in vertebrates and in some invertebrates such as annelids. From these different researches, it appears that mammalian innate immunity could be considered as a mosaic of invertebrate immune responses. Annelids belonging to the lophotrochozoans' group are primitive coelomates that possess specially developed cellular immunity against pathogens including phagocytosis, encapsulation and spontaneous cytotoxicity of coelomocytes against allogenic or xenogenic cells. They have also developed an important humoral immunity that is based on antimicrobial, hemolytic and clotting properties of their body fluid. In the present review, we will emphasize the different immunodefense strategies that adaptation has taken during the course of evolution of two classes of annelids i.e. oligochaetes and achaetes.
\end{abstract}

Keywords : Annelids, innate immunity, antimicrobial peptides, hemolytic substances, cytokines 


\section{Introduction}

In the course of evolution annelids have developed different immunodefense strategies against microbes living in water or soil that are ingested during feeding or introduced into the body after injury [1]. For understanding immune processes, it is necessary to briefly review annelid anatomy. Earthworms (Oligochaeta, oligochaetes) and leeches (Hirudinea, achaetes) are characterized by the presence of two compartments containing free cells: (a) the blood system with haemocytes: this compartment does not seem to be actively implied in immunity and (b) the coelom that includes several coelomocytes populations playing a role in the immune defense Fig. (1). We focus in the present review on Oligochaeta and. Hirudinea in which most of the work on immunodefense has been performed. Both are important for certain biomedical applications [2-4].

\section{I- Cellular immune responses in annelids}

\section{A Phagocytosis by LC and NK-like lysis by SC}

In oligochaetes, spontaneous allogeneic cytotoxicity of coelomocytes from Eisenia fetida and Lumbricus terrestris has been investigated in vitro using different assays (trypan blue, lactate dehydrogenase and ${ }^{51} \mathrm{Cr}$ release; FACS analyses) [5, 6]. Suzuki and Cooper investigated xenogenic reactions against human tumor cells [6]. TEM and SEM studies showed that close contact of target cells with Lumbricus effector cells (coelomocytes with different mitochondrial properties) [7] is followed by lysis. The results confirm that effector cell/target cell contact is essential for cytotoxicity to occur. These cytological events support analogies with cytotoxic activities that are affected when vertebrate natural killer cells are cocultured with appropriate targets. Cytotoxicity supports the postulate of Cooper [8] and later Franceschi[9] that a primitive natural killer cell-like (analogue vertebrate NK cells) evolved early in phylogenesis [8-11] and the following results support this view. As in the NK system, the target specificity is exceedingly broad since xenogenic, allogenic, and even syngenic red blood targets are killed under appropriate conditions. The specificity of these cytotoxic cells may be directed at cell-surface glycoproteins on target cell surfaces since several defined mono- and disaccharides can block killing. Suzuki and Cooper examined whether modifying cell surface antigens can affect the level of cell-mediated cytotoxicity[12]. When co-cultured with small coelomocytes (SC) with NK-sensitive cells lines (K592), they become agitated, extending numerous pseudopodia that bind to and kill targets cells [13]Figs. (2A, 2B)- Large coelomocytes (LC) aggregate around the lysed targets and encapsulate them before forming granulomas [13]. These results suggest that phagocytosis and cytotoxicity are independently mediated by two different cell types; earthworm leukocytes as a group are polyfunctional and not exclusively phagocytic [4]. This supports the view of early divergence of phagocytosis and lysis.

The use of monoclonal antibodies directed against several human CD markers enabled Cossarizza et al to focus on these two coelomocytes in E. fetida [14]: (1) the SC also called killer cells which are positive for CD11 a ${ }^{+}, \mathrm{CD}_{4} 5 \mathrm{RA}^{+}, \mathrm{CD} 45 \mathrm{RO}^{+}, \mathrm{CDw}_{49} \mathrm{~b}^{+}, \mathrm{CD} 54^{+}, \beta_{2}-\mathrm{m}^{+}$ and Thy $-1^{+}$(CD90) and (2) the phagocytic LC that are negative for these markers [15]; [16]. Both cell types were negative for numerous other CD and MHC class I and class II markers. [17]. SC are active during recognition, rapidly binding to targets and LC are phagocytic. One cell group the $\mathrm{SC}$ effects recognition, binding and killing, whereas cleaning up the remaining debris rests with the other cell type the LC. 
In achaetes, differential $\mathrm{CD}$ staining at different time points following grafting experiments (four months between two transplants and specimen examination after 1 month), assume the presence of two different cell types, i.e. NK-like cells and CD8 ${ }^{+}$cells in the medicinal leech (generally classified as cytotoxic lymphocytes in vertebrates) $[18,19]$. These coelomocytes are selectively stimulated by different antigens [19]. De Eguileor and colleagues using morphological and immunocytochemical approaches have analyzed the migratory behavior of cells involved in inflammatory responses of Glossiphonia complanata [18] as well as angiogenesis processes [20, 21]. Like other annelids, leech leukocytes phagocytose and encapsulate foreign material selectively depending upon size [22]. Encapsulation is optimally visible when a parasite has been completely coated and isolated by a thick melanotic capsule [22]. Wounding in leeches is accompanied by "leucopoiesis", as it is generally accepted in vertebrates. In fact, in transplanted/wounded leeches, massive proliferation of lymphocyte-like cells stemming from a single cluster has been observed [22].

\section{II- Humoral immune responses in annelids}

\section{A. Is there evidence of complement like activity?}

Both, cellular and humoral immune reactions in annelids are increased in response to an inflammatory or intracoelomic injection of foreign material. Certain annelid immune mechanisms, like NK-like activity and pore formation resemble functionally perforin and/or complement activity of vertebrates. The protective mechanisms of invertebrates consist, beyond cell immunity, of lysis and agglutination enhanced by components from the coelomic fluid like antigen binding protein, cytokines, antimicrobial substances. Results in the field of research are numerous, especially in oligochaetes. In several experiments designed to test the possible existence of complement like activity, Cooper [23]co-cultured earthworm leukocytes with various NK dependent and independent targets [23]. Since washed coelomocytes were always used in cytotoxic assays, the experiments were done to test the capacity of cell-free supernatants. Adding supernatant from coelomocytes cultured for $10 \mathrm{~min}$ at $22^{\circ} \mathrm{C}$ caused significant cytotoxicity against K562 and other human cell lines. Cytotoxicity was not evident when supernatants from the same (autogenic) or different (allogenic) earthworms were added immediately after washing, nor did cytotoxicity occur when supernatants were heated at $56^{\circ} \mathrm{C}$ for $30 \mathrm{~min}$ before addition to K562 cultures. This suggests that a humoral factor-mediated component that may be complement like protein is involved in a significant percentage of target cell killings. Cytotoxicity cannot be interpreted as effected primarily by earthworm leukocytes.

\section{B- Hemolytic substances}

\section{A recognition component}

A coelomic cytolytic factor (CCF) has been isolated from coelomic fluid of the earthworm E. fetida [24].CCF-1 shared functional analogy with vertebrate TNF based on $\mathrm{N}, \mathrm{N}$-diacetylchitobiose lectin like domain/activity, despite a gene or protein homology [25]. This suggests that CCF and TNF lectin domain have been functionally conserved in the course of evolution as a recognition mechanism during innate immune responses [26]. CCF-1 is capable of lysing different mammalian tumor cell lines but by contrast with TNF, this cytolytic activity is mediated by lysis and is not due to proteolysis. Interestingly, CCF-1 recognizes lysozyme-predigested Gram-positive bacteria or the peptidoglycan constituent muramyl dipeptide as well as muramic acid (Fig.3) [27]. The broad specificity of CCF for 
pathogen-associated molecular patterns results from the presence of two distinct pattern recognition domains. One domain, which shows homology with the polysaccharide and glucanase motifs of beta-1, 3-glucanases and invertebrate defense molecules located in the central part of the CCF polypeptide chain, interacts with LPS and beta-1,3-glucans. The Cterminal tryptophan-rich domain mediates interactions of CCF with N,N'-diacetylchitobiose and muramic acid Fig.(3). These data provide evidence for the presence of spatially distinct carbohydrate recognition domains within this invertebrate immunodefense molecule [28] [27].

\section{Pore forming molecules}

Besides CCF-1, pore-forming proteins have been characterized in the earthworm coelom: i.e. eiseniapore [29, 30], lysenin [31] and fetidin[32] (table 1) These molecules bind to and disturb the lipid bilayer only when particular sphingolipids, (e.g. sphingomyelin), are present which are lacking in annelids[33, 34]. As for lysenin, cholesterol enhances eiseniapore lytic activity toward sphingomyelin-containing vesicles. Leakage of vesicles was most efficient when the lipid composition resembled that of the outer leaflet of human erythrocytes [35] [33]. Electron microscopy of erythrocyte membranes confirmed ring-shaped structures (pores). The channel complex consists of six monomers $[29,30]$ suggesting a plausible explanation for the mechanism by which components of the earthworm's immune system destroy non-self components Fig. (3).

In addition, Kauschke et al. have demonstrated the existence of a perforin-like protein [36] [37]. Perforin and other lytic molecules seemed to be linked. One explanation is that perforin will generates the holes in target cell membranes facilitating the entry the lytic molecules like lysenins, lysins, fetidins and the hemolysins $\left(\mathrm{H}_{1}, \mathrm{H}_{2}, \mathrm{H}_{3}\right)$ 33. [38] [39] [32] (Table 1). Each of these molecules has been demonstrated to be active towards certain human diseases (Nieman-Pick; blood clots).

\section{Cytokines and mitogenic factors}

Most of the data obtained at the present time on cytokines in invertebrates are by antibody recognition and not by sequence similarity. In annelids, the most data concerns the oligochaetes [40] and also leeches [41, 42]. With respect to mitogenic factors, one was initially discovered in Lumbricus that exerts activity on $\mathrm{T}$ cells [43]. Later, a $60-\mathrm{kDa}$ component with mitogenic activity on murine splenocytes was identified in the coelomic fluid of E. fetida and named CMF (Coelomic Mitogenic Factor) [44]. CMF was found to bind ConA that could account for its ability to inhibit ConA-induced spleen cell proliferation. CMF is a trimer of a $20-\mathrm{kDa}$ protein. N-terminal amino acid sequence of monomeric CMF reveals partial sequence homology with phospholipase A2 (PLA2). Moreover, CMF-enriched coelomic fluid exerts phospholipase activity comparable with that of bovine pancreatic PLA2. These results suggest that coelomic fluid of E. foetida contains an ubiquitous PLA2-like enzyme which might be involved in immune reactions in earthworms such as anti-bacterial mechanisms [44].

\section{Antigen-binding proteins (ABP)}

Laulan et al. reported synthesis by $L$. terrestris of specific substances in response to an immunization with a synthetic hapten [45]. Tuckova et al identified a $56 \mathrm{kDa}$ molecule, antigen-binding protein consisting of two disulfide-linked polypeptide chains (31 and $33 \mathrm{kDa}$ ) 
both of which participate in the formation of the antigen-binding site [46]. The kinetics of $\mathrm{ABP}$ formation revealed that the response reached a maximum level between the 4th and the 8th day after the first dose and approximately 4 days after the second challenge. The degree of specificity of the ABP after the secondary in vivo challenge increased, but even so it was considerably lower than that of vertebrate immunoglobulin [47].

\section{E. Antimicrobial proteins}

The most studied antimicrobial protein in annelids is the lysozyme [48] Table (1). This is an enzyme that cleaves the $\beta-1-4$ bonds between $N$ acetylglucosamine and $N$ acetylmuramic acid of Gram positive bacterial cell walls. Lysozyme is often detected using its action against Microccocus lysodeikticus.

In oligochaetes, background activity was 20 -fold enhanced by one injection of either Gram positive or Gram negative bacteria and sheep red blood cells. Maximum induced activity occurred 4-5 hr after injection. Transcription and translation regulation of lysozyme have been investigated by Hirigoyenberry et al [49]. Besides, lysozyme activity, the coelomic fluid of the earthworm E.fetida andrei exhibits antibacterial, hemolytic and hemagglutinating activities (See the cytotoxicity section). These activities are mainly mediated by two proteins, named fetidins, of apparent molecular mass $40 \mathrm{kDa}$ and $45 \mathrm{kDa}$, respectively [32]. The recombinant protein was showed to inhibit Bacillus megaterium growth. Near its hemolysis activity, the protein also exhibits a peroxydase activity and a peroxydase signature was identified in residues 52-62 [32] Table (1).

In achaetes, an intrinsic lysozyme-like activity was demonstrated for destabilase [50, 51]. Several isoforms of destabilase constitute a protein family with at least two members characterized by lysozyme activity $[50,51]$. The corresponding gene family implies an ancient evolutionary history of the genes although the function(s) of various lysozymes in the leech remains unclear. Differences in primary structures of the destabilase family members and members of known lysozyme families allow one to assign the former to a new family of lysozymes. New proteins homologous to destabilase were recently described for Caenorhabditis elegans and bivalve molluscs suggesting that the new lysozyme family can be widely distributed among invertebrates $[50,51]$. Besides lysozyme, a $14 \mathrm{kDa}$ protein sharing a bacteriostatic activity and belonging to the hemerythrin family has been found in fat cells [52] as well as glial cells of leeches[53]. Hemerythrin is a non-hemic-iron oxygen-transport protein acting as an iron scavenger towards bacteria in polychaetes [54] Table (1).

\section{F. Antimicrobial peptides}

During the last few years studies on the components of the innate immune system fully demonstrated the contribution of the antimicrobial peptides to host defense. Antibiotic peptides are small molecules (size comprised between $2 \mathrm{kDa}$ and $8 \mathrm{kDa}$ ). Their implication in natural resistance to infection is sustained by their strategic location in phagocytes, in body fluids and at epithelial cell levels i.e. at interfaces between organisms and its environment [55](Table (1).

In oligochaetes, an antimicrobial peptide named lumbricin I has been isolated and characterized from the earthworm, Lumbricus rubellus. Lumbricin I is a proline-rich antimicrobial peptide of 62 amino acids. Lumbricin I showed antimicrobial activity in vitro against a broad spectrum of microorganisms without hemolytic activity. A 29-amino acid peptide, named lumbricin I (6-34), which was derived from residues 6-34 of lumbricin I, showed marginally stronger antimicrobial activity than authentic lumbricin I. However lumbricin I gene is not induced by bacterial infection, but was constitutively expressed. 
Furthermore, the expression of lumbricin I gene was specific in adult L. rubellus, no expression was found in eggs and young L. rubellus [56].

In achaetes, Tasiemski et al., have recently isolated four antimicrobial peptides from the coelomic fluid of the leech Theromyzon tessulatum: theromacin, theromyzin, peptide B [57-59] $[60,61]$ and lumbricin sharing high sequence homology with the one isolated from earthworm (unpublished data). Theromacin is a cationic 75 amino acids peptide with 10 cysteines residues arranged in a disulfide array showing no obvious similarities with other known antimicrobial peptides [59] [62]. Theromyzin and peptide B are anionic peptides of 82 and 31 amino acid residues respectively [58, 59] [62] [63]. Theromacin and theromyzin are processed from a larger precursor constituted by a signal peptide directly followed by the active peptide. Interestingly, peptide $B$ is processed from the $C$ terminal part of proenkephalin A (PEA), the major precursor of enkephalins. Peptide B and theromyzin possess bacteriostatic activity by contrast with theromacin which exhibit potent bactericidal activity towards Gram positive bacteria. Theromyzin is a histidine rich peptide sharing a HXXE, divalent ion active site like histatin in vertebrates [64]. Analysis of theromacin and theromyzin gene expression demonstrated both a developmental and a septic injury induction in large fat cells (LFC), which constitute a specific tissue that seems to be a functional equivalent of the insect fat body (Figure 2D, 2E). Both peptides seem to exert their antimicrobial activity by a systemic action. All these data suggest for the first time an innate immune response in a lophotrochozoan comparable to the antibacterial response of an ecdysozoan i.e. D. melanogaster. Consequently, Theromyzon is an original invertebrate model which has developed two modes of fighting infections by antimicrobial peptides: (i) storage of antibacterial peptide derived from PEA, particularly in coelomocytes and/or in nervous system, and release of the peptide into the coelomic fluid after immune challenge (ii) induction after septic injury of gene coding for more classical antimicrobial peptide, mainly in LFC, and rapid release into the body fluid of the antibiotic peptides Fig.(4).

\section{G. Cysteine and serine protease inhibitors}

Serine proteases, such as trypsin, thrombin, granzyme B, are important enzymes involved in regulating many physiologic events including the extrinsic pathways of blood coagulation and immune processes. In the immune system, killer lymphocytes combine the activity of a membranolytic protein, perforin, and the serine protease granzyme B to induce target cell apoptosis [65]. Similarly, cysteine proteases such as capthepsins are implicated in processing functions of mammalian antigen presenting cells (APCs) [66]. They allow Class II-antigenic peptide binding by degradation of Ii chaperone in the initial Class II-Ii complex [67].

In oligochaetes, three serine proteases have been isolated from E. fetida leukocytes and one is related to trypsin [68]. In the same species, a serine protease inhibitor of $14 \mathrm{kDa}$ contained in the coelomic fluid has been characterized [69]. This enzyme inhibitor shares high homologies with several plant serine protease inhibitors. These molecules seem to be implicated in the cytotoxic cascade involving fetidins, CCF and the prophenoloxidase system Fig. (3) [33].

In achaetes, a gene tandem cystatin B (Tt-cysb)-cathepsin L (Tt-catl) was identified in the leech T. tessulatum [70]. Tt-cysb belongs to the cysteine protease inhibitor family. Tt-cysb gene possesses an open reading frame of 306 nucleotides without signal peptide. The deduced 
sequence presents $54 \%$ sequence identity with human cystatin B. No homologs of $T t$-cysb are present in D. melanogaster and C. elegans genomes. The active site sequence (QXVXG) is conserved as well as the glycine at position 5 allowing its interaction with its substrate, the cathepsin L. Tt-cysb constitutes the first cystatin B protein isolated in invertebrates. Tt-catl belongs to the cysteine proteinase family and presents $68 \%$ sequence identity with $D$. melanogaster cathepsin L. Tt-cysb is only expressed in one circulating coelomic cells population. Bacterial challenge leads to an enhancement of the Tt-cysb transcript exclusively in these cells. Double in situ hybridization showed cathepsin L gene (Tt-catl) to be expressed in the same cells suggesting that both $T t$-cyst and Tt-catl gene products might play a role in immune regulation through these circulating coelomic cells Fig.( 2F). These data are in line with those evidenced in mammals or in drosophila in which cathepsin $\mathrm{L}$ is present in small granules of haemocytes and might play a role in phagocytic events [71] [70].

\section{Perspectives concerning annelid immunity}

Arthropods, especially insects, represent an important group of invertebrates because of their sheer numbers, and Drosophila has provided ample evidence that they possess effective innate immune responses. Yet it is unwise to over-generalize about the immune system of all invertebrates based upon this single species. If one looks at metazoan phylogeny based on small subunit rRNA, certain interesting revelations emerge. There are two major groups, the pre-bilaterians and the bilateria, the latter being subdivided into two major groups, the protostomes and deuterostomes. Of the protostomes, in turn, there are two subgroups, the Lophotrochozoa, to which the annelids and mollusks belong, and the Ecdysozoa to which the arthropods and nematodes belong. Although it will not be discussed here, the dominant body of evidence with respect to innate immunity and its relation to vertebrate (mammalian) and plants concerns findings in two ecdysozoan species, Drosophila and C. elegans. In contrast, lophotrochozoan systems show some distinct differences and may have solved problems of immunodefense in a special manner as has been revealed here with respect to two groups of annelids [3]. Annelids are among the first coelomates and are therefore of special phylogenetic interest. Polychaetes which we did not focus on in this review, are restricted to the marine domain and are considered as the most primitive annelids, based on morphology, physiology and development. Oligochaetes and achaetes are considered as being more evolved as reflected in their immune systems. Compared to other invertebrate groups, data on annelid's immunity reveal heavier emphasis on the cellular than on the humoral response suggesting that immune defense of annelids seems to be principally developed as cellular immunity $^{37}$. However, the Expressed Sequence Tag (EST) sequencing programs on Lumbricus terrestris (LumbriBASE; http://www.earthworms.org and the leech Hirudo medicinalis (http://genome.uiowa.edu/projects/leech/), combined with microarrays techniques developed on these models and imaging mass spectrometry will allow acquisition of more information about leech and earthworm humoral immunity. Our preliminary transcriptomic data obtained in leeches Table (2) dealing with immune responses suggest that this strategy is feasible and that substantial new knowledge will be obtained by analysing lophotrochozoans. This will only lead to further expansion of the two existing schemes that have been proposed concerning earthworm Fig. (3) and leech Fig. (4) immune responses. In this expanse, we predict more relevant biomedical/clinical applications further than what already exists.

\section{Acknowledgment}

This work was in part supported by the CNRS, the MNERT, the FEDER, the Conseil Regional Nord Pas de Calais, the Genopole of Lille, the Plateau de Proteomique de l'USTL and the NIH-Fogarty Grant. E.L. Cooper is supported by the Alexander von Humboldt 
Foundation and GAAC grant from the Federal Rebublic of Germany and two grants from NATO, Cooperative Research Grant (971128) and Advanced Research Workshop (976680).

\section{Bibliography}

[1] Dhainaut, A., Scaps, P. Can. J. Zool., 2001, 79, 233-253.

[2] Sima, P.; Vetvicka, V. Crit Rev Immunol, 1993, 13, 83-114.

[3] Cooper, E. L.; Kauschke, E.; Cossarizza, A. Bioessays, 2002, 24, 319-33.

[4] Cooper, E. L.; Kauschke, E.; Cossarizza, A. Adv Exp Med Biol, 2001, 484, 169-83.

[5] Valembois, P., Roch, and Boiledieu, D. In Phylogeny of immunological memory, M.G. Manning, ed.; Elsevier-North Holland Biomedical Press: Amsterdam, 1980, pp. 47-55.

[6] Suzuki, M. M.; Cooper, E. L. Nat Immun, 1995, 14, 11-9.

[7] Cossarizza, A.; Cooper, E. L.; Quaglino, D.; Salvioli, S.; Kalachnikova, G.; Franceschi, C. Biochem Biophys Res Commun, 1995, 214, 503-10.

[8] Cooper, E. L. Endeavor, 1981, 4.

[9] Franceschi, C.; Cossarizza, A.; Monti, D.; Ottaviani, E. Eur J Immunol, 1991, 21, 48993.

[10] Cooper, E. L., Wright, R.K., Stein, E.A., Roch, P.J., Mansour, M.H. Immunity in earthworms and tunicates with special reference to receptor origins, Karger 1987.

[11] Cooper, E. L., Roch, P. G., Wright, R. K. Phylogeny of mononuclear phagocytes, University of Tokyo Press: Tokyo 1982.

[12] Suzuki, M. M.; Cooper, E. L. Zoolog Sci, 1995, 12, 443-51.

[13] Quaglino, D.; Cooper, E. L.; Salvioli, S.; Capri, M.; Suzuki, M. M.; Ronchetti, I. P.; Franceschi, C.; Cossarizza, A. Eur J Cell Biol, 1996, 70, 278-8.

[14] Cossariza, A. Exp. Cell. Res., 1996, 224, 174-182.

[15] Roch, P.; Cooper, E. L.; Eskinazi, D. P. Eur J Immunol, 1983, 13, 1037-42.

[16] Engelmann, P., Pal, J., Berki, T., Cooper, E. L., Nemeth, P. Zoology, 2002, 105, $257-$ 265.

[17] Cooper, E. L. In Invertebrate immunology, B. and Muller Rinchevich, W.E.G., ed.; Springer-Verlag: Heidelberg, 1996, pp. 10-45.

[18] de Eguileor, M.; Grimaldi, A.; Tettamanti, G.; Valvassori, R.; Cooper, E. L.; Lanzavecchia, G. Tissue Cell, 2000, 32, 437-45.

[19] de Eguileor, M.; Grimaldi, A.; Tettamanti, G.; Valvassori, R.; Cooper, E. L.; Lanzavecchia, G. Tissue Cell, 2000, 32, 40-8.

[20] de Eguileor, M.; Tettamanti, G.; Grimaldi, A.; Perletti, G.; Congiu, T.; Rinaldi, L.; Valvassori, R. Curr Pharm Des, 2004, 10, 1979-88.

[21] Tettamanti, G.; Grimaldi, A.; Valvassori, R.; Rinaldi, L.; de Eguileor, M. Cytokine, 2003, 22, 168-79.

[22] de Eguileor, M.; Tettamanti, G.; Grimaldi, A.; Congiu, T.; Ferrarese, R.; Perletti, G.; Valvassori, R.; Cooper, E. L.; Lanzavecchia, G. Curr Pharm Des, 2003, 9, 133-47.

[23] Cooper, E. L.; Cossarizza, A.; Suzuki, M. M.; Salvioli, S.; Capri, M.; Quaglino, D.; Franceschi, C. Cell Immunol, 1995, 166, 113-22.

[24] Bilej, M.; Brys, L.; Beschin, A.; Lucas, R.; Vercauteren, E.; Hanusova, R.; De Baetselier, P. Immunol Lett, 1995, 45, 123-8.

[25] Beschin, A.; Bilej, M.; Brys, L.; Torreele, E.; Lucas, R.; Magez, S.; De Baetselier, P. Nature, 1999, 400, 627-8.

[26] Beschin, A.; De Baetselier, P.; Bilej, M. Bioessays, 2002, 24, 974; author reply 975-6.

[27] Beschin, A.; Bilej, M.; Magez, S.; Lucas, R.; De Baetselier, P. Prog Mol Subcell Biol, 2004, 34, 145-63. 
[28] Bilej, M.; De Baetselier, P.; Van Dijck, E.; Stijlemans, B.; Colige, A.; Beschin, A. J Biol Chem, 2001, 276, 45840-7.

[29] Lange, S.; Nussler, F.; Kauschke, E.; Lutsch, G.; Cooper, E. L.; Herrmann, A. J Biol Chem, 1997, 272, 20884-92.

[30] Lange, S.; Kauschke, E.; Mohrig, W.; Cooper, E. L. Eur J Biochem, 1999, 262, 54756.

[31] Sekizawa, Y.; Kubo, T.; Kobayashi, H.; Nakajima, T.; Natori, S. Gene, 1997, 191, $97-$ 102 .

[32] Lassegues, M.; Milochau, A.; Doignon, F.; Du Pasquier, L.; Valembois, P. Eur J Biochem, 1997, 246, 756-62

[33] Cooper, E. L., Roch, P. Pedobiologia, 2003, 47, 676-688.

[34] Milochau, A.; Lassegues, M.; Valembois, P. Biochim Biophys Acta, 1997, 1337, 123 32

[35] Shakor, A. B.; Czurylo, E. A.; Sobota, A. FEBS Lett, 2003, 542, 1-6.

[36] Kauschke, E., Pagliara, P., Stanbili, L., and Cooper, E.L. Comp Biochem Physiol, 1997, 116, 235-242.

[37] Porchet-Henneré, E.; Dugimont, T. Dev. Comp. Immunol., 1992, 16, 263-274.

[38] Eue, I.; Kauschke, E.; Mohrig, W.; Cooper, E. L. Dev Comp Immunol, 1998, 22, 1325.

[39] Koenig, S.; Wagner, F.; Kauschke, E.; Peter-Katalinic, J.; Cooper, E. L.; Eue, I. Dev Comp Immunol, 2003, 27, 513-20.

[40] Beck, G.; Habicht, G. S. Sci Am, 1996, 275, 60-3, 66.

[41] Dormer, A.; Beck, G. In Silico Biol, 2005, 5, 0030.

[42] Tettamanti, G.; Grimaldi, A.; Ferrarese, R.; Palazzi, M.; Perletti, G.; Valvassori, R.; Cooper, E. L.; Lanzavecchia, G.; de Eguileor, M. Tissue Cell, 2003, 35, 199-212.

[43] Wojdani, A.; Stein, E. A.; Alfred, L. J.; Cooper, E. L. Immunobiology, 1984, 166, 157 67.

[44] Hanusova, R.; Bilej, M.; Brys, L.; De-Baetselier, P.; Beschin, A. Immunol Lett, 1999 , 65, 203-11.

[45] Laulan, A.; Lestage, J.; Chateaureynaud-Duprat, P.; Fontaine, M. Ann Immunol (Paris), 1983, 134D, 223-32

[46] Tuckova, L.; Rejnek, J.; Bilej, M.; Pospisil, R. Dev Comp Immunol, 1991, 15, 263-8.

[47] Bilej, M.; Tuckova, L.; Romanovsky, A. Folia Microbiol (Praha), 1995, 40, 436-40.

[48] Perin, J. P.; Jolles, P. Biochim Biophys Acta, 1972, 263, 683-9.

[49] Hirigoyenberry, F.; Lassalle, F.; Lassegues, M. Comp Biochem Physiol B, 1990, 95, 71-5.

[50] Baskova, I. P.; Zavalova, L. L.; Basanova, A. V.; Sass, A. V. Biochemistry (Mosc), 2001, 66, 1368-73.

[51] Baskova, I. P.; Zavalova, L. L. Biochemistry (Mosc), 2001, 66, 703-14.

[52] Coutte, L.; Slomianny, M. C.; Malecha, J.; Baert, J. L. Biochim Biophys Acta, 2001, $1518,282-6$

[53] Vergote, D.; Sautiere, P. E.; Vandenbulcke, F.; Vieau, D.; Mitta, G.; Macagno, E. R.; Salzet, M. J Biol Chem, 2004, 279, 43828-37.

[54] Deloffre, L.; Salzet, B.; Vieau, D.; Andries, J. C.; Salzet, M. Neuroendocrinol Lett, 2003, 24, 39-45.

[55] Vizioli, J.; Salzet, M. Trends Pharmacol Sci, 2002, 23, 494-6.

[56] Cho, J. H.; Park, C. B.; Yoon, Y. G.; Kim, S. C. Biochim Biophys Acta, 1998, 1408 , 67-76. 
[57] Tasiemski, A.; Salzet, M.; Benson, H.; Fricchione, G. L.; Bilfinger, T. V.; Goumon, Y.; Metz-Boutigue, M. H.; Aunis, D.; Stefano, G. B. J Neuroimmunol, 2000, 109, 228-35.

[58] Tasiemski, A.; Verger-Bocquet, M.; Cadet, M.; Goumon, Y.; Metz-Boutigue, M. H.; Aunis, D.; Stefano, G. B.; Salzet, M. Brain Res Mol Brain Res, 2000, 76, $237-52$.

[59] Tasiemski, A., Vizioli, J., Vandenbulcke, F., Sautiere, P.E., Lemoine, J., Salzet, M. In 9th international congress of I.S.D.C.I.: St Andrews, Scotland, 2003

[60] Salzet, M. Trends Immunol, 2001, 22, 285-8.

[61] Salzet, M. Trends Immunol, 2002, 23, 283-4.

[62] Tasiemski, A.; Vandenbulcke, F.; Mitta, G.; Lemoine, J.; Lefebvre, C.; Sautiere, P. E.; Salzet, M. J Biol Chem, 2004, 279, 30973-82.

[63] Salzet, M.; Tasiemski, A. Dev Comp Immunol, 2001, 25, 177-85.

[64] Oppenheim, F. G.; Xu, T.; McMillian, F. M.; Levitz, S. M.; Diamond, R. D.; Offner, G. D.; Troxler, R. F. J Biol Chem, 1988, 263, 7472-7.

[65] Trapani, J. A.; Jans, D. A.; Jans, P. J.; Smyth, M. J.; Browne, K. A.; Sutton, V. R. J Biol Chem, 1998, 273, 27934-8.

[66] Barrera, C.; Ye, G.; Espejo, R.; Gunasena, S.; Almanza, R.; Leary, J.; Crowe, S.; Ernst, P.; Reyes, V. E. Hum Immunol, 2001, 62, 1081-91.

[67] Riese, R. J.; Chapman, H. A. Curr Opin Immunol, 2000, 12, 107-13.

[68] Roch, P.; Cooper, E. L. Ecotoxicol Environ Saf, 1991, 22, 283-90.

[69] Roch, P.; Ville, P.; Cooper, E. L. Dev Comp Immunol, 1998, 22, 1-12.

[70] Lefebvre, C.; Cocquerelle, C.; Vandenbulcke, F.; Hot, D.; Huot, L.; Lemoine, Y.; Salzet, M. Biochem J, 2004, 380, 617-25.

[71] Tryselius, Y.; Hultmark, D. Insect Mol Biol, 1997, 6, 173-81.

\section{Figures Legends}

\section{Figure 1:}

Earthworm (Lumbricus terrestris) cross section through intestinal region. Annelids in general are characterized by a blood system (dorsal and ventral vessels) and a body fluid system contained in the coelomic cavities. Only the components of the coelomic fluid were shown to participate to the immune defense.

\section{Figure 2:}

A, B: Earthworm cytotoxic cell activity; Small effector (E) coelomocyte in contact with K562 human targets (T), before (A) and after 5 min interaction (B). (with permission from [12]). C: Negative staining transmission electron microscopy of eiseniapore-treated sheep erythrocyte membranes. The image clearly shows many pore-like structures with an outer diameter of 10 $\mathrm{nm}$. (with permission from [30]) D. Immune localization of theromacin and theromyzin, two antimicrobial peptides in the leech Theromyzon tessulatum. Theromacin and theromyzin signals are detected in large fat cells (LFC) in close contact with the body fluid of the leech. E: On semi-thin sections using an immunogold procedure, positive signals to theromacin were observed at the periphery of the LFC and in coelomic cavities (CC).

F: Confocal microscopy analysis with anti-cystatin B (green) and anti-cathepsin L (red) in large coelomic cells of the leech Theromyzon tessulatum.

Figure 3: Hypothetical scheme of the putative innate immune response in earthworm involving cytotoxic factors. Septic injury provoke the release of Coelomocyte Cytolytic Factor I (CCF-I) from coelomocytes. CCF-1 possesses two distinct domains i.e. the N- 
terminal domain interacts with lipopolysaccharide and $\beta$ 1.3-glucans and the C-terminal domain mediates its interactions with $\mathrm{N}$, N-diacetylchitibiose and muranic acid [28]. CCF-1 can trigger the prophenoloxydase cascade (pro-PO) implicating serine proteases and fetidins (Fe). CCF-1 also enhances phagocytosis by its opsonizing properties and potentiates lysis against various erythrocytes. CCF-1 can be considered as a pattern recognition molecule exerting a key role in the innate immune response of earthworm. Catalytic factors (fetidness, eiseniapore (EP), lysenins (Ly) are released from chloragocytes and coelomocytes [30-32]. These proteins bind to and disturb the lipid bilayer only when particular sphingolipids are present and perform pore channels.

Figure 4: Hypothetical scheme of the putative innate immune response of leeches involving antibacterial peptides. Septic injury provokes an important production of mucous that would trap bacteria present in the external environment of the leech. Then, trapped bacteria would be killed by theromacin and theromyzin present in the mucous. At the same time, injury would induce theromacin and theromyzin gene expression and the secretion of the gene products from the LFC into the body fluid of the animal [59]. Thus, theromacin and theromyzin would exert their antimicrobial property through a systemic action. Moreover, antibacterial peptide (peptide B) as well as immune activator (Methionine Enkephalin (Met-Enk)) derived from proenkephalin A (PEA), particularly in coelomocytes and/or in nervous system, are released into the coelomic fluid after immune challenge [58]. This would lead, in conjunction with the phagocytic action of coelomocytes containing cystatin B (Tt-cysb) and cathepsin L (Tt-catl), to the microbial killing in the body fluid [72]. 